\title{
Cytokine expression in normal, atopic, and asthmatic subjects using the combination of sputum induction and the polymerase chain reaction
}

\author{
C M Gelder, P S Thomas, D H Yates, I M Adcock, J F J Morrison, P J Barnes
}

\begin{abstract}
Background - The importance of cytokines in the asthmatic inflammatory response is becoming apparent. The aim of this study was to determine whether the non-invasive method of induced sputum combined with the polymerase chain reaction would allow the detection of messenger RNA (mRNA) encoding a range of cytokines on a qualitative basis.

Methods - Four groups were studied comprising 10 normal subjects, six atopic, 10 mild and five moderately severe asthmatic subjects. Sputum was induced by the inhalation of nebulised $3.5 \%$ saline and total RNA extracted from the expectorated cells. Expression of cytokine message within induced sputum was examined by reverse transcription and the polymerase chain reaction (PCR) using primers specific for a range of cytokines (IL-1 $\alpha$, IL-2, IL-3, IL-4, IL-5, IL-6, IL-8, RANTES, TNF $\alpha$, IFN $\alpha$, IFN $\gamma$ ). Presence or absence of the signal was determined at 35 and 70 cycles of PCR by electrophoretic size fractionation on ethidium bromide stained agarose gels.
\end{abstract}

Results - Cytokine message was detectable in sputum by this method. All samples showed a positive result for actin control. Analysis of signal for the cytokines in all subjects showed that, at 70 cycles, IL-1, IL-5, IL-8, and TNF $\alpha$ were detected in more subjects than would be expected by chance. IL-5 mRNA was detected in more of the asthmatic patients (moderate $80 \%$, mild $40 \%$ ) than in the atopic subjects $(33 \%)$, who in turn showed expression of this cytokine in more individuals than nonatopic subjects $(10 \%)$.

Conclusions - The combination of sputum induction and PCR appears to be a useful, non-invasive tool to explore the chronic inflammation of asthma and possibly other lung disorders. It should enable differences between normal and asthmatic subjects to be identified for future confirmation by quantitative techniques.

(Thorax 1995;50:1033-1037)

Keywords: cytokines, atopy, asthma.
Cytokines are important modulators of the immune system and have been implicated in the pathogenesis of the inflammatory aspects of asthma, particularly those produced by activated $\mathrm{TH}_{2}$-like lymphocytes such as $\mathrm{IL}-4$ and IL $-5 .^{1-3}$ Asthmatic subjects have increased expression of mRNA encoding a number of cytokines including IL -5 in bronchial biopsy tissue ${ }^{4}$ and in bronchoalveolar lavage (BAL) fluid. ${ }^{3}$

Both bronchoalveolar lavage and bronchial biopsy are associated with sampling problems and hazards, while the technique of sputum induction provides a non-invasive way to assess pulmonary inflammation. ${ }^{5}$ Sputum induction allows repeated sampling to be safely carried out as an outpatient procedure, even in those who have quite severe asthma. Combining the techniques of sputum induction and the polymerase chain reaction (PCR) may allow qualitative examination of the expression of a range of cytokine genes on small quantities of material. Using only a single sample this method could allow the simultaneous investigation of a range of cytokines which are now considered to function within interdependent networks, rather than independently. ${ }^{1}$

We have examined samples from a group of mild asthmatic patients who required only occasional inhaled $\beta_{2}$ agonists to control their symptoms, and a group of more severe asthmatic patients who required inhaled steroid therapy. As controls we used a group of nonatopic normal subjects, and a group of nonasthmatic atopic subjects.

\section{Methods}

SUBJECTS

Ten normal, six atopic non-asthmatic and 15 asthmatic individuals were studied in a protocol approved by the Royal Brompton Hospital ethics committee.

Normal subjects $(n=10)$ were defined by a negative history for asthma or allergy, negative skin prick tests to four common allergens, normal IgE, normal lung function tests, and log provocative concentration of methacholine causing a $20 \%$ fall in forced expiratory volume in one second $\left(\mathrm{PC}_{20}\right)$ of $>32 \mathrm{mg} / \mathrm{ml}$. Atopic subjects $(n=6)$ were defined by one or more 
Characteristics of subjects

\begin{tabular}{|c|c|c|c|c|c|c|c|c|}
\hline $\begin{array}{l}\text { Subject } \\
\text { no. }\end{array}$ & Sex/Age & $\begin{array}{l}\% \text { predicted } \\
F E V_{1}\end{array}$ & $\begin{array}{l}\text { Methacholine } \\
P C_{20}(\mathrm{mg} / \mathrm{ml})\end{array}$ & $\begin{array}{l}I g E I U / l \\
(n<150)\end{array}$ & $\begin{array}{l}\text { Total peripheral } \\
\text { blood eosinophils }\left(10^{9} / \mathrm{ml}\right)\end{array}$ & $\begin{array}{l}\text { Skin } \\
\text { tests }\end{array}$ & $\begin{array}{l}\text { Years since } \\
\text { smoked }\end{array}$ & Medication/day \\
\hline \multicolumn{9}{|c|}{ Normal subjects } \\
\hline 1 & $M, 24$ & 109 & $>32$ & 78 & $0 \cdot 3$ & - & Never & - \\
\hline 2 & $M, 35$ & 107 & $>32$ & 30 & ND & - & Never & Fluoxetine \\
\hline 3 & $M, 46$ & 124 & $>32$ & 9 & $0 \cdot 3$ & - & & - \\
\hline 4 & $M, 25$ & 95 & $>32$ & 5 & $0 \cdot 3$ & - & 4 & - \\
\hline 5 & $\mathrm{M}, 20$ & 109 & $>32$ & 21 & $0 \cdot 1$ & - & 0.5 & - \\
\hline 6 & $M, 61$ & 119 & $>32$ & 51 & 0 & - & Never & - \\
\hline 7 & $M, 23$ & 90 & $>32$ & 12 & 0 & - & Never & - \\
\hline 8 & $\mathrm{~F}, 28$ & 104 & $>32$ & 4 & 0 & - & Never & - \\
\hline 9 & $M, 25$ & 102 & $>32$ & 16 & 0 & - & Never & - \\
\hline 10 & $M, 29$ & 98 & $>32$ & 6 & $0 \cdot 1$ & - & 0.5 & - \\
\hline \multicolumn{9}{|c|}{ Atopic subjects } \\
\hline 1 & $M, 23$ & 86 & $>32$ & 308 & $1 \cdot 2$ & - & Never & - \\
\hline 2 & $\mathrm{~F}, 21$ & 106 & $19 \cdot 9$ & 123 & $0 \cdot 2$ & + & Never & - \\
\hline 3 & $\mathrm{~F}, 40$ & 120 & $6 \cdot 4$ & 40 & $0 \cdot 3$ & ND & & - \\
\hline 4 & M,36 & 79 & $>32$ & 162 & 0.6 & - & Never & Sulphasalazine \\
\hline 5 & $M, 38$ & 112 & $>32$ & 51 & $0 \cdot 1$ & + & & - \\
\hline 6 & $M, 37$ & 92 & $13 \cdot 2$ & ND & $0 \cdot 1$ & - & Never & - \\
\hline \multicolumn{9}{|c|}{ Asthmatic subjects } \\
\hline 1 & $\mathrm{M}, 32$ & 100 & $2 \cdot 5$ & 112 & $0 \cdot 2$ & + & Never & $\begin{array}{l}\text { Salbutamol prn } \\
<200 \mu \mathrm{g} / \text { day }\end{array}$ \\
\hline 2 & $M, 20$ & 97 & $1 \cdot 2$ & 37 & 1 & ND & Never & $\begin{array}{l}\text { Salbutamol prn } \\
<200 \mu \mathrm{g} / \text { day }\end{array}$ \\
\hline 3 & $M, 53$ & 82 & $0 \cdot 48$ & 537 & $0 \cdot 4$ & + & Never & $\begin{array}{l}\text { Salbutamol prn } \\
<200 \mu \mathrm{g} / \text { day }\end{array}$ \\
\hline 4 & $M, 21$ & 91 & $0 \cdot 16$ & 683 & 0.3 & + & Never & $\begin{array}{l}\text { Salbutamol prn } \\
<200 \mu \mathrm{g} / \text { day }\end{array}$ \\
\hline 5 & $\mathrm{~F}, 32$ & 89 & $0 \cdot 23$ & 61 & 0.3 & + & Never & $\begin{array}{l}\text { Salbutamol prn } \\
<200 \mu \mathrm{g} / \text { day }\end{array}$ \\
\hline 6 & $F, 23$ & 92 & 0.098 & ND & ND & + & Never & $\begin{array}{l}\text { Salbutamol prn } \\
<200 \mu \mathrm{g} / \text { day }\end{array}$ \\
\hline 7 & $\mathrm{~F}, 32$ & 97 & $2 \cdot 6$ & 332 & $0 \cdot 1$ & + & Never & $\begin{array}{l}\text { Salbutamol prn } \\
<200 \mu \mathrm{g} / \text { day }\end{array}$ \\
\hline 8 & $M, 23$ & 80 & $0 \cdot 44$ & 294 & $0 \cdot 2$ & + & 2 & $\begin{array}{l}\text { Salbutamol prn } \\
<200 \mu \mathrm{g} / \text { day }\end{array}$ \\
\hline 9 & $M, 31$ & 109 & $>32$ & 23 & $0 \cdot 1$ & + & Never & $\begin{array}{l}\text { Salbutamol prn } \\
<200 \mu \mathrm{g} / \text { day }\end{array}$ \\
\hline 10 & $\mathrm{M}, 33$ & $96 \cdot 2$ & 32 & 38 & $0 \cdot 2$ & + & Never & $\begin{array}{l}\text { Salbutamol prn } \\
\text { Budesonide } 14 \\
\text { days earlier }\end{array}$ \\
\hline \multicolumn{9}{|c|}{ Asthmatic subjects on inhaled corticosteroids } \\
\hline 1 & $\hat{\mathbf{M}}, 40$ & 79 & $4 \cdot 1$ & 212 & $0 \cdot 2$ & + & Never & \multirow{2}{*}{$\begin{array}{l}\text { Salbutamol prn } \\
\text { Budesonide } 1.6 \mathrm{mg} \\
\text { Salbutamol prn } \\
\text { Budesonide } 1.6 \mathrm{mg}\end{array}$} \\
\hline 2 & $M, 26$ & 68 & $0 \cdot 11$ & 196 & ND & + & Never & \\
\hline 3 & $\mathrm{~F}, 26$ & 86 & 0 & 142 & $0 \cdot 2$ & + & Never & $\begin{array}{l}\text { Terbutaline prn } \\
\text { Budesonide } 1.6 \mathrm{mg}\end{array}$ \\
\hline 4 & $M, 61$ & 61 & $1 \cdot 1$ & ND & ND & + & 15 & $\begin{array}{l}\text { Salbutamol prn } \\
\text { Beclomethasone } 2 \mathrm{mg} \\
\text { Phenobarbitone }\end{array}$ \\
\hline 5 & $M, 25$ & 85 & $3 \cdot 9$ & 216 & $0 \cdot 2$ & + & 1 & $\begin{array}{l}\text { Salbutamol prn } \\
\text { Beclomethasone } 0.4 \mathrm{mg}\end{array}$ \\
\hline
\end{tabular}

$\mathrm{FEV}_{1}=$ forced expiratory volume in one second; $\mathrm{PC}_{20}=$ provocative concentration of methacholine causing a $20 \%$ fall in $\mathrm{FEV}$; $\mathrm{ND}=$ not determined

of the following ${ }^{6}$ : skin prick test to aeroallergen $>2 \mathrm{~mm}$ greater than control, history of atopy (seasonal rhinitis, eczema), elevated IgE but no history of asthma. This group had a $\mathrm{PC}_{20}$ of $>6 \mathrm{mg} / \mathrm{ml}$. Asthmatic patients $(n=15)$ were defined by seasonal wheezing, peak flow variability of $>15 \%$ with response to bronchodilators, with or without an abnormal methacholine $\mathrm{PC}_{20}$ (all except two subjects had a $\mathrm{PC}_{20}$ of $<6 \mathrm{mg} / \mathrm{ml}$ and these two subjects had definite evidence of airway variability). They were divided into two groups: (1) a mild group treated only with inhaled $\beta_{2}$ agonists $(n=10)$ and (2) a moderate group requiring inhaled corticosteroids $(n=5)$.

A summary of the subject characteristics is shown in the table.

SPUTUM INDUCTION

Subjects inhaled nebulised $3.5 \%$ saline, voluntarily coughed every 2.5 minutes until the first of either $5 \mathrm{ml}$ of sputum was expectorated or 20 minutes was reached. ${ }^{5}$ Sputum was solubilised by dithiothreitol in Hank's buffered salt solution (HBSS), washed, resuspended in HBSS, and the total number of cells counted.
An aliquot of cells was cytocentrifuged, fixed, stained, and differential cell count performed by applying standard morphometric criteria to the first 400 identifiable pulmonary cells. A further aliquot was stored in denaturing solution $^{7}$ (guanadinium, sarcosyl, $\beta$-mercaptoethanol) for cytokine RNA analysis.

\section{MOLECULAR METHODS}

Total RNA was extracted using the acidguanadinium thiocyanate-phenol-chloroform method. ${ }^{7}$ RNA was precipitated with isopropranol using glycogen, resuspended in denaturing solution, reprecipitated, and washed with ethanol. Adjustments ensured that RNA from an equivalent number of pulmonary cells was used for reverse transcription. Reverse transcription (RT) was performed as follows: $18 \mu \mathrm{l}$ of the RNA sample was combined with $4 \mu \mathrm{l}$ of the oligo dT (15) primer $(100 \mathrm{mg} / \mathrm{ml})$, heated to $60^{\circ} \mathrm{C}$ for 10 minutes, placed on ice, and combined with $18 \mu \mathrm{l}$ of a reaction mix. The reaction mixture comprised (final concentration): reverse transcriptase buffer $(10 \mathrm{mM}$ Tris $\mathrm{HCl}, 50 \mathrm{mM} \mathrm{KCl}, 0 \cdot 1 \%$ Triton $\mathrm{X}-100), \operatorname{dnTPs}(1 \mathrm{mM}), \mathrm{MgCl}_{2}(2 \cdot 5 \mathrm{mM}), 0 \cdot 1$ 


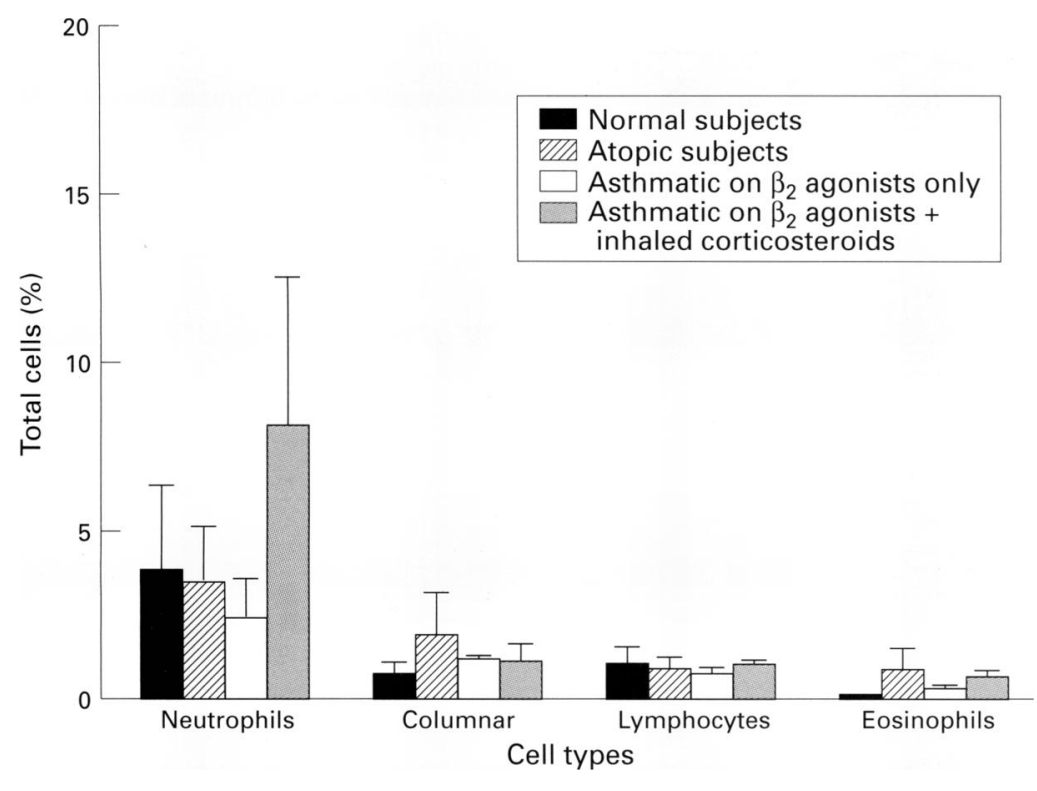

Figure 1 Mean (SE) differential cell count as percentage of total by subject group. The remainder of the pulmonary cells were macrophages. The increased number of neutrophils in the more severe asthmatic group was not significant.

Figure 2 Single gel demonstrating DNA size fractionation by agarose gel electrophoresis. Ethidium bromide staining shows cDNA product after 70 cycles of RT-PCR upon induced sputum samples from four sequential subjects. Lane 1, IL-1 $\alpha$; 2 , $I L-1 \beta, 3, I L-2 ; 4, I L-3$; 5, IL-4; 6, IL-5; 7, IL-6; 8, IL-8; 9, negative control; 10, GM-CSF; 11 $T N F \alpha ; 12, I F N \alpha ; 13$, IFN $\beta ; 14, I F N \gamma$. Individual samples: $A$, normal; $B$, mild asthmatic subject; $C$, atopic subject; $D$, mild asthmatic subject. All lanes except control show migration of primers in a single, uniform band front. Lanes with a positive result have a larger fragment migrating more slowly, which is visible above the primer front. unit rRNase inhibitor (Promega), 0.5 units AMV reverse transcriptase (Promega). The reaction was incubated at $42^{\circ} \mathrm{C}$ for 90 minutes, then terminated by heating to $80^{\circ} \mathrm{C}$ for 10 minutes. The resultant cDNA solution was diluted and used as a template for each PCR reaction.

PCR was performed in duplicate under the following conditions (final concentration): $10 \mu \mathrm{l}$ cDNA, PCR buffer (Promega), nucleotides $(0.2 \mathrm{mM})$, forward primer $(0.25 \mathrm{mM})$,

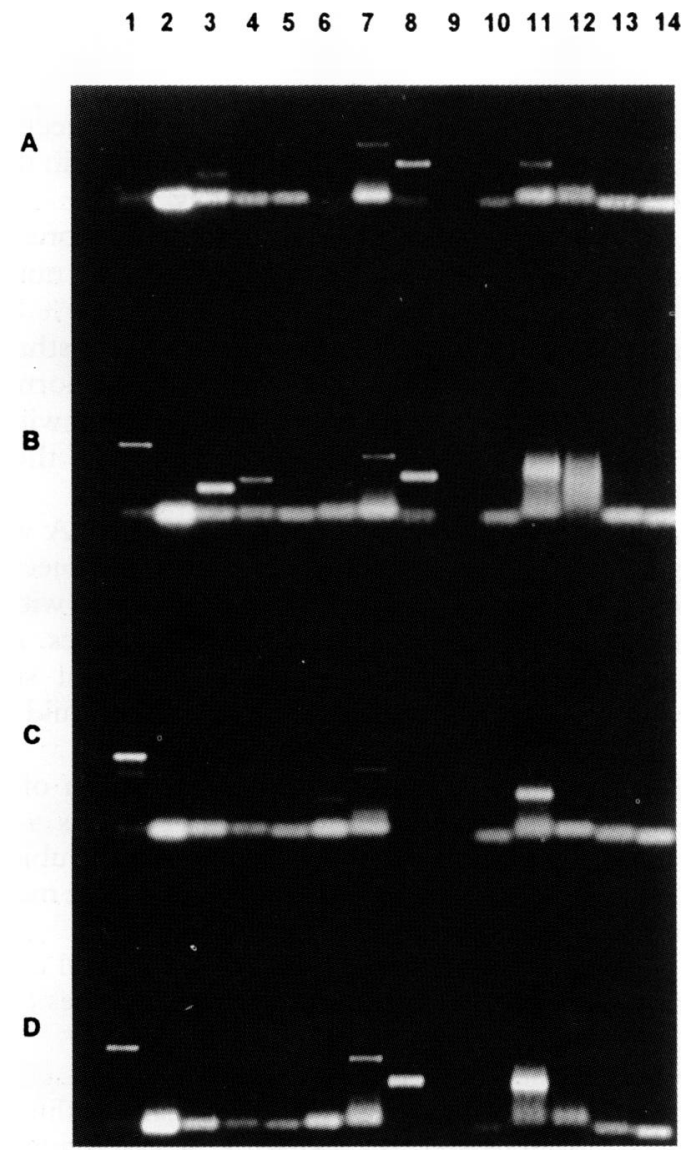

reverse primer $(0.25 \mathrm{mM}), 1.6$ units Taq polymerase (Promega). Thermocycling conditions were: $95^{\circ} \mathrm{C}$ for five minutes followed by 35 cycles of $95^{\circ} \mathrm{C}$ for 30 seconds, $55^{\circ} \mathrm{C}$ for 30 seconds, $72^{\circ} \mathrm{C}$ for 60 seconds, followed by $72^{\circ} \mathrm{C}$ for five minutes.

After 35 cycles an aliquot was diluted tenfold and this was added to a fresh reaction mixture for a second series of 35 cycles using the same conditions. Products were size fractionated on $3 \%$ agarose gel containing ethidium bromide, photographed, and assessed in a blinded manner. Apart from the determination at 35 and 70 cycles, no further attempt was made at quantification.

Primers specific for $\beta$-actin mRNA were used as a positive control at 35 cycles, histidyl tRNA synthetase specific primers were used as a sensitive control for DNA contamination, ${ }^{8}$ and samples without cDNA were used as negative controls. Specificity was confirmed by product sequencing.

\section{PRIMERS}

The following primer pairs were used:

IL- $1 x \quad 5$ ' GCAGAAGTACCCTAAGCTCGCCAGTGAAAT 3' CATCTTTCAACACGCAGGACAGGTACAGAT

IL-2 5' GATGCAACTCCTGTCTTGCATTGCACTAAG

3' TTAAATGTGAGCAGCCTGGTAGAGTTTGGGA

IL-3 5' CCATGACCCAGACAACGTCCTTGAAGACAA

3' TCAGTTTCCTCCGGAATTCATTCCAGTCAC

IL-4 5' ATGGGTCTCACCTCCCAACTG

3' TCAGCTCGAACACTTTGAATATTTCTCTCTCAT

IL-5 5' GTGCACTGAAGAAATCTTTCAGGGAATAGG

3' CACTCGGTGTTCATTACACCAAGAAACTCT

IL-6 5' GCTATGAACTCCTTCTCCACAAGCGCCTCC

3' GACTTTTGTACTCATCTGGACAGCTCTGGC

IL-8 5' ATGACTTCCAAGCTGGCCGTG

3' TTATGAATTCTCAGCCCTCTTCAAAAACTTCTC

RANTES $5^{\prime}$ TCATTGCTACTGCCCTCTGC

3' GAGAAACCTCTACTCGATCC

TNF $\alpha \quad 5^{\prime}$ CCTGGAAAGGACACCATGAGCACTGAAAGC

3' TGCCTGGGCCAGAGGGCTGATTAGAGAGAG

IFN $\alpha$ 5' TCCATGAGAGATTCCAGCAG

3' ATTTCTCGCTCTGACAACCTCCC

IFN $\gamma \quad 5^{\prime}$ GCTCTGCATCGTTTTGGGTTCTCTTGGCTG

3' CCTTTTTCGCTTCCCTGTTTTAGCTGCTGG

Histidyl tRNA Synthetase

$$
\begin{aligned}
& \text { 5' CTTCAGGGAGAGAGCGCGTGCG } \\
& \text { 3' TCATCAGGACCCAGCTGTGC } \\
& \text { 5' GTGGGGCGCCCCAGGCACCA } \\
& \text { 3' CTCCTTAATGTCACGCACGATTTC }
\end{aligned}
$$$$
\text { B-Actin } 5^{\prime} \text { GTGGGGCGCCCCAGGCACCA }
$$

Primers for other cytokines (IL-1 $\beta$, GMCSF, IFN $\beta$ ) were tried but not found to be satisfactory and are not discussed further.

\section{DATA ANALYSIS}

Nominal data were analysed by the $\chi^{2}$ test with the Bonferroni correction or by Fisher's exact test for small samples; ANOVA was used for data conforming to the Normal distribution.

\section{Results}

Sputum induction was well tolerated and without adverse side effects. Mean differential cell counts showed no differences between the groups: slightly more neutrophils were seen in 

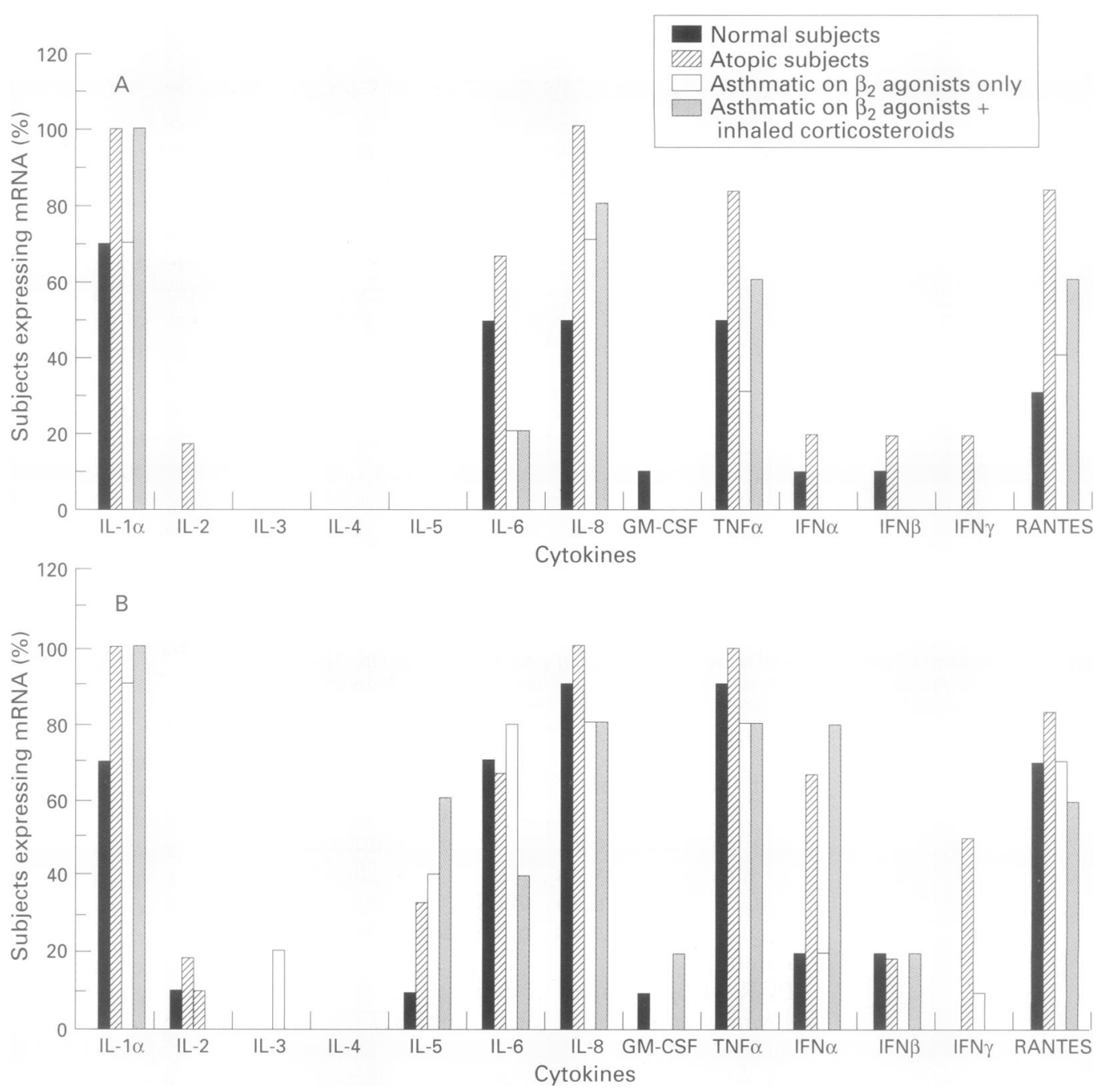

Figure 3 Percentage of subjects with a detectable signal for individual cytokines after (A) 35 cycles and (B) 70 cycles of polymerase chain reaction.

the severe asthmatic group but the difference was not statistically significant $(p>0.05$, ANOVA; fig 1). Gels as shown in the example in fig 2 were analysed by a blinded observer. RT-PCR results are expressed as the percentage of subjects showing the presence of the appropriate band (fig 3). Analysis of $\mathrm{mRNA}$ for these cytokines showed that, at 35 cycles, most subjects had a signal for IL-1 and IL -8 while, at 70 cycles, IL-1, IL-5, IL-8, and TNF $\alpha$ were detected in more subjects than would be expected by chance ( 35 and 70 cycles, $\mathrm{p}<0.002$ for each of the above cytokines, $\chi^{2}$ test).

Little expression of mRNA for IL-2, IL-3, or IL -4 was detected. (As a positive control, the primers for IL -3 and IL -4 were subsequently tested upon an activated lymphocyte clone and found to be active.)

IL-5 mRNA was not detected at 35 cycles but at 70 cycles it was expressed by $10 \%$ of normal subjects, $33 \%$ of atopic subjects, $40 \%$ of mild asthmatics, and $80 \%$ of severe asthmatics. There was a significant difference in the percentage showing IL-5 expression between asthmatic and non-asthmatic groups $(p<0.05$, Fisher's exact test). IL-6 was expressed at 35 cycles by $50 \%$ of normal subjects, $66 \%$ of atopic subjects, and $20 \%$ of asthmatic subjects, while at 70 cycles the expression increased to
$70 \%$ in normal subjects, $66 \%$ in atopic subjects, and $60 \%$ and $40 \%$ in the two asthmatic groups, respectively.

IL-8 mRNA expression was detected at 35 cycles in $50 \%$ of normal subjects, $100 \%$ of atopic subjects, $70 \%$ and $80 \%$ respectively of the two groups of asthmatics, while at 70 cycles the expression in normal subjects increased to $90 \%$ and in those with mild asthma to $80 \%$. The expression of the other two groups was unchanged.

RANTES mRNA was seen at 35 cycles in $30 \%$ of normal subjects, $83.3 \%$ of atopic subjects, $40 \%$ of those with mild asthma, and $60 \%$ of severe asthmatics. At 70 cycles it was seen in $70 \%$ of normal subjects, $83 \%$ of atopic subjects, $70 \%$ of mild asthmatics, and $60 \%$ of severe asthmatics.

No clear pattern of mRNA expression was seen for interferons $\alpha$ or $\gamma$, while message for TNF $\alpha$ was almost ubiquitous with virtually all subjects expressing message for this gene at 70 cycles.

The actin control mRNA was detected in all samples at 35 cycles.

\section{Discussion}

This study shows the feasibility of performing cytokine message analysis upon induced spu- 
tum samples. It introduces a non-invasive way of studying a large number of cytokines simultaneously in a group of designated individuals with a particular disease and enables comparison with normal subjects. The method that we used is qualitative and not quantitative, which allows a screening procedure to be performed thus reducing labour, time, and cost. Once trends in the cytokine expression have been demonstrated, more sophisticated techniques of quantitative PCR could be used. The final proof of a particular cytokine being involved in a pathway has, however, to be the demonstration of the presence of the protein itself, rather than just the RNA message. Mild and moderate asthma were associated with more frequent expression of IL -5 , which would agree with previously published work on bronchial biopsy samples. ${ }^{4}$ More asthmatic subjects had an IL-5 message than those with atopy alone, more of those with severe disease than mild asthma, perhaps reflecting differences in the numbers of activated $\mathrm{TH}_{2}$-like lymphocytes. A potential role for IL -5 in the pathogenesis of asthma exists as it mediates eosinophil migration and survival and, in association with the pattern of RANTES expression, may at least partially account for the eosinophilia associated with asthma. ${ }^{4}$

This study also suggests that at 35 cycles of PCR there may be more frequent expression of IL-8 and RANTES in induced sputum from those with atopy and asthma than from normal subjects. The difference was seen at 35 and not at 70 cycles, implying a quantitative difference in expression. Both of these cytokines have been implicated in the pathogenesis of asthma. IL-8 has important effects on neutrophil and eosinophil migration and activation $^{910}$ and RANTES is also chemotactic for eosinophils. These results need to be confirmed by further investigation, but IL -8 has been described in association with BAL fluid from asthmatic subjects. ${ }^{1112}$

Little difference was seen in IL-1 and TNF $\alpha$ expression between normal and asthmatic subjects. IL -3 and IL -4 mRNA were not detected in this study despite positive controls confirming the activity of the primers. This is contrary to the findings of Robinson $e t a l^{\beta}$ and others who have studied IL $-4,{ }^{11}$ but the differences may be partially technical since our asthmatic subjects expectorated few lymphocytes or eosinophils. This may reflect the fact that all asthmatic subjects were deliberately chosen while in a stable phase of their disease. A non-significant trend to a sputum neutrophilia was seen in the asthmatic group on inhaled corticosteroids. The cytokine profile of neutrophils includes $\mathrm{IL}-1 \alpha$ and $\beta, \mathrm{IL}-8, \mathrm{IFN} \alpha$, and $\mathrm{TNF} \alpha$, some of which may be participating in the inflammatory response.

Our results support the concept that cytokines have a role in the pathogenesis of asthma, particularly IL-5, and perhaps IL-8 and RANTES. These results are in agreement with those studies performed on bronchoalveolar lavage specimens and bronchial biopsy tissue. ${ }^{341112}$ In this study atopy was associated with very similar findings to asthma, and there may be no clear distinction between the two conditions if they are part of an allergic disease spectrum.

We believe that the combination of induced sputum and RT-PCR is easily performed. Repeated non-invasive samples can be taken and sensitive quantification techniques, such as competitive RT-PCR and radioimmunoassay, could be applied to the cytokines implicated by this technique. Sputum induction is well tolerated and when combined with PCR provides a useful tool for the investigation of the pathogenesis of asthma.

1 Katz MF, Beer DJ. Lymphocytes and cytokine networks in asthma: clinical and therapeutic implications. Adv Intern Med 1993;38:189-219.

2 Brown PH, Crompton GK, Greening AP. Pro-inflammatory cytokines in acute asthma. Lancet 1991;338:590-3.

3 Robinson DS, Hamid Q, Ying S, Tsicopoulos A, Barakans $\mathrm{J}$, Bentley AM, et al. Predominant Th-2 like bronchoalveolar T-lymphocytes in atopic asthma. $N$ Engl $\mathcal{f}$ Med 1992;236:298-304.

4 Hamid Q, Azzawi M, Ying S, Moqbel R, Wardlaw AJ, Corrigan CJ, et al. Expression of mRNA for interleukin5 in mucosal biopsies from asthma. $\mathcal{F}$ Clin Invest 1991;87: 1541-6.

5 Fahy JV, Liu J, Wong H, Boushey Jr HA. Cellular and biochemical analysis of induced sputum from asthmatic and healthy subjects. Am Rev Respir Dis 1993;147:112631 .

6 Cookson WOCM, Hopkin JM. Dominant inheritance of atopic immunoglobulin E responsiveness. Lancet 1988; ; 86-7.

7 Chomczynski P, Sacchi N. Single-step method of RNA isolation by acid guanidinium thiocyanate-phenol-chloroisolation by acid guanidinium thiocyanate-pheno

8 Corrochano LM. A test of human CDNA synthesis by the polymerase chain reaction. Genet Anal Tech Appl 1991;8: 134-5.

9 Lynch JP, Standiford TJ, Rolfe MW, Kunkel SL, Strieter RM. Neutrophilic alveolitis in idiopathic pulmonary fibrosis. The role of interleukin-8. Am Rev Respir Dis 1992, 145: 1433-9.

10 Villar MTA, Douglass J, Shute J, Church MK, Holgate ST. Interleukin-8 is a chemoattractant for eosinophils primed with interleukin-4. Am Rev Respir Dis 1993;147:A242.

11 Walker C, Bauer W, Braun RK, Menz G, Braun P, Schwar F, et al. Activated T cells and cytokines in bronchoalveolar $\mathrm{F}$, et al. Activated T cells and cytokines in bronchoalveolar lavages from patients with various lung diseases associated
with eosinophilia. Am $₹$ Respir Crit Care Med 1994;150: with eosing

12 Hallsworth MP, Soh CPC, Lane SJ, Arm JP, Lee TH Selective enhancement of GM-CSF, TNF $\alpha$, IL-1 $\beta$ and IL -8 production by monocytes and macrophages of asthmatic subjects. Eur Respir f 1994;7:1096-102. 